\title{
The struggle against poverty, unemployment and social injustice in present-day South Africa: Exploring the involvement of the Dutch Reformed Church at congregational level
}

\author{
Van der Westhuizen, Marichen \\ Stellenbosch University \\ mvdw@hugenote.com \\ Swart, Ignatius \\ University of South Africa \\ swartil@unisa.ac.za
}

\begin{abstract}
This article is based on an exploration of the involvement of the Dutch Reformed Church (DRC) at congregational level in the struggle against poverty, unemployment and social injustice in present-day South Africa. The exploration arises from the thesis that South African citizens continue to regard poverty, unemployment and social injustice as the key challenges to be met in order to build a healthy nation. Historically, the DRC acted as a prominent partner of the government to address the basic needs of the poor and the sick, especially among the country's white population. But the structural and social changes that followed the transformation to the new democratic South Africa impacted significantly on this partnership. This in turn required that the role of the DRC in addressing social issues in the country be revisited. The essential purpose of this article is, firstly, to provide better insight into the nature and extent of the current social services rendered by congregations of the DRC in addressing the challenges of poverty, unemployment and social injustice; and secondly, from this vantage point, to present some recommendations in conclusion on how the DRC could, in terms of its own striving towards even deeper and more effective social engagement, further enhance its contribution to address the identified challenges at congregational level.
\end{abstract}

\section{Keywords}

Dutch Reformed Church, congregations, poverty, unemployment, social injustice 


\section{Introduction}

After more than two decades of democracy "South Africa is still battling with issues of poverty, inequality, unemployment and hunger" (Statistics South Africa, 2013a:22). This reality is also reflected in the latest Pulse of the People research study, which identifies the most important challenges to be met by the South African government as unemployment (87\%), poverty (59\%) and crime (57\%) (Ipsos 2014). Two aspects related to these research findings should be noted. Firstly, the issues of concern were identified by old and young people, employed and unemployed citizens, and supporters of the three biggest parties in Parliament. Secondly, these issues have remained the same since 1994 (Ipsos 2014).

The issues mentioned above have a bearing on the social services rendered by the Christian church. Historically, churches in general and on an international level have been key role-players in service delivery to the poor, sick and needy (Lidzén 2008:1-7). In Africa the family was viewed as the primary carer. This changed when Christianity came to the continent. Lidzén (2008:1) explains that the church took on the role of a "surrogate family" and that it worked in close partnership with governments and the states over which those governments preside.

In South Africa the Dutch Reformed Church (DRC) was closely associated with the ruling Nationalist Party in the period before 1994. Services by this church were aligned with viewpoints and policies of the government of the day (Clark, Fage, Oliver \& Roberts 1975:564-565; Kritzinger 1994:5253; Van der Merwe 2012:148-149, 152-163; Van der Merwe 2014:14-20, 8385). Furthermore, the DRC's involvement in poverty relief stems from the severe poverty among white people during the 1880s and subsequent decades (Kritzinger 1994:50-53; Terreblanche 2002:266; Van der Merwe 2012:147-148). It became known as the "Poor White Problem". Fourie (2006:1) notes that the Dutch Reformed Church Synod first discussed the causes of the poor white problem in 1886. These causes included "...the inadequate education system, urbanisation, cheap wages or cultural factors, while others argued that external events such as the rinderpest disease or the Anglo-Boer war added to the numbers of poor whites" (cf. Kritzinger 1994:50; Van der Merwe 2012:147-148). Fourie explains that, by the early 1930s, efforts to eradicate the Poor White Problem became a “...social, 
economic and political" objective. As a result, the Carnegie Commission investigated the causes and consequences to find corrective measures in 1932. Services of Benevolence by the church were consequently based on the outcome of the Carnegie Report (Fourie 2006:4-5; cf. Kritzinger 1994:50-52).

One of the changes that occurred during the transformation to a new democratic South Africa was that of the relationship and link between the DRC and the new government. The DRC, therefore, had to redefine its role within the new South African dispensation (Van der Merwe 2012:154-162; Van der Merwe 2014:80-122).

This article is informed by a research project commissioned by the General Synod of the DRC to undertake a preliminary exploration of the nature and extent of the DRC's involvement at congregational level in combating the problems of poverty, unemployment and social injustice in presentday South African society (Van der Westhuizen, 2013:1). The findings of the research project are used in this article to achieve the following two aims: to provide better insight into the nature and extent of current social services rendered by congregations of the DRC in addressing the challenges of poverty, unemployment and social injustice; and, from this vantage point, to conclude with some recommendations on how the DRC could, in terms of its own striving towards even deeper and more effective social engagement, further enhance its contribution towards addressing the identified challenges at congregational level.

The challenges of poverty, unemployment and social injustice in the South African context are discussed first. This is followed by a more general discussion of the social function of the church at congregational level. Pertaining to the DRC in particular, the findings of the aforementioned project are then discussed, followed in conclusion by an identification of particular three areas of strategic concern through which it is recommended that the DRC could further enhance its engagement with the identified challenges at congregational level. 


\section{Key social challenges in present-day South Africa: poverty, unemployment and social injustice}

\subsection{Poverty}

Despite interventions by international and national role-players, approximately one billion people worldwide experience extreme poverty (Cohen, 2009:8). In South Africa, by comparison, 10.2 million people (approximately $20.2 \%$ of the population) lived below the breadline of R321.00 per month in 2011. As a result, the South African government views the challenge of poverty alleviation as a key priority. This is evident when one considers that close to $60 \%$ of government expenditure is allocated to social grants and that expenditure related to social wages has more than doubled over the past decade (Statistics South Africa, 2013a:22; Statistics South Africa, 2013b:8). This entails that "the proportion of the budget spent on social services has increased by 15 percentage points, from $45 \%$ in $1994 / 95$ to $60 \%$ in 2014/15" (Moloi 2015:2).

Considering that addressing the problem of poverty has remained one of the primary concerns of the South African people since 1994, the longterm effect of social grants as a means to address poverty is not only unclear but also problematic. In terms of grant allocation by the South African government, it is noted by Statistics South Africa's Millennium Development Goals Country Report (2013a:22) that "the overarching policy of government to address Millennium Development Goal 1 (MDG 1) is through the provision of a 'social wage' package intended to reduce the cost of living of the poor". SSA also noted that one should investigate the impact of social wages on the "triple challenge of poverty, unemployment and inequality" (Statistics South Africa 2013a:22). Steele (2006:86) asserts in this regard that social grants should be viewed as an emergency mechanism to alleviate poverty, but that it cannot be seen as a means to reduce poverty as this could lead to dependency and inhibits the development of potential. Effective poverty reduction therefore remains a challenge.

This article acknowledges the link between poverty, unemployment and social injustice (Statistics South Africa 2013a:22). The discussion, furthermore, draws strongly on the theory of structural poverty. Within the framework of this theory, it is postulated that poverty is caused by unequal distribution of, and/or lack of access to, material and non-material 
resources. The first refers to basic needs, while the second refers to access to opportunities. For the purpose of this article the authors, therefore, worked from the premise that social injustice arises when access to material and non-material resources is not equally distributed and that this lack of access hampers development and therefore sustains poverty (Bradshaw 2006:4; Loewen 2009:7). The theory of structural poverty is furthermore based on the belief that the vulnerability of people is the result of a lack of assets, resources and opportunities, on the one hand. On the other hand, the theory is based on the conviction that such vulnerability is caused by people's inability to react effectively to social problems. This would imply that the way people deal with a lack of assets, resources and opportunities will determine how poverty will be addressed (Richmond 2007:11). In this regard Patel (2009:242) asserts that the reduction of poverty depends on the creation of viable social networks and trustful relationships between individuals, groups and communities. It implies that a community that suffers from poverty-related issues is a mirror image of the social interactions and processes of that very same community.

Social processes refer to two dynamics, namely opposition and/or cooperation. On the one hand, opposition is associated with competition and conflict that direct the social interactions. Cooperation, on the other hand, refers to accommodation, assimilation and acculturation that support the development of interactions conducive to social harmony (Farooq, 2012:13). The degree to which government and the state, the business sector and civil society (including the church) become involved and collaborate therefore impacts on the way in which poverty is dealt with (Richmond, 2007:4). According to this viewpoint, partnerships between the mentioned role-players, including people affected by poverty, will lead to a fair distribution of resources, knowledge, skills and responsibilities (Handmaker \& Berkhout 2010:ii; National Planning Commission 2011:14). In addition, actions directed towards poverty alleviation should take into account and include the viewpoints of the poor. An international study in 2009 investigated the viewpoints of communities of 15 African, South and East Asian, and South American countries regarding poverty and poverty reduction, and identified seven aspects that should be considered when interventions are planned: 
1. Poverty is not the product of a culture: people dream of success and of moving out of poverty;

2. Poverty is a condition and not a characteristic: when opportunities are created potential can develop;

3. Internal power bases are needed to develop potential: this requires empowerment;

4. Equal opportunities are the dream: social justice contributes to poverty alleviation and reduction;

5. Reactive local democracy can address poverty: fair and compassionate leadership is needed;

6. Collective actions assist people to deal with poverty, but not to move out of poverty;

7. Programmes should include beneficiaries as active role-players to ensure sustainable change (Narayan, Pritchett \& Kapoor, 2009:18-42).

\subsection{Unemployment}

While short-term assistance aims to provide immediate poverty relief (e.g. in the form of social grants and food parcels), human and economic capital development are aimed at poverty reduction (Department of Social Development 2013:7). Within the framework of the theory of structural poverty, this means that employment opportunities, or the lack thereof, are associated with and fundamentally impact on sustainable poverty reduction. Employment, therefore, leads to the ability to provide for one's own and/or one's family's basic needs. According to the National Development Agency (2014:72), there is a clear link between ongoing poverty and unemployment. This becomes evident when one considers that $72 \%$ of non-poor persons are permanently employed compared to $40 \%$ of persons living in poverty.

It is estimated that, on an international level, 197 million people in the world are unemployed (International Labour Organization 2013). In South Africa unemployment during the second quarter of 2014 was $25.5 \%$ (Statistics South Africa 2014), including a disturbingly high unemployment rate among the country's youths. South Africa has the third highest youth 
unemployment rate in the world, affecting approximately $50 \%$ of South African youths (World Economic Forum 2014:14).

There is a wide variety of causes of unemployment in South Africa. One cause is the fact that there is an over-supply of unskilled labour and a larger group of women entering the labour market (Levinsohn 2007:2). This points towards structural unemployment, referring to a mismatch between demand and supply in the workforce (e.g. no employment opportunities for persons with a specific skill). An alarming aspect is that two other forms of unemployment are often not reflected in statistics (Cohen 2009:18). Frictional unemployment refers to a period between employment opportunities, which may be voluntary or because of economic reasons. Hidden unemployment refers to potential workers who are excluded from employment opportunities (e.g. preference for a specific group and thereby excluding another group).

In addition, Levinsohn (2007:4) identifies three consequences of unemployment, namely a loss of economic outputs, a dynamic impact of skills and knowledge not being utilised and developed, and the difficult-tomeasure phenomenon of a nation losing hope.

As mentioned before, the South African people identified government as the main service provider to meet the challenges of poverty and unemployment, amongst other social challenges. The South African government acknowledges this aspect. The Minister of Finance agreed (on 26 February 2014) that unemployment and poverty were priority areas to be addressed. In addition, the Minister acknowledged government as the primary agent responsible for generating the means to address these problems, but emphasised that the effectiveness of such attempts are dependent on partnerships with other financial and civic institutions (Ministry of Finance 2014:1).

\subsection{Social injustice}

This article is based on an investigation of the DRC's present-day involvement in poverty, unemployment and social injustice. In terms of social justice, one should remain cognisant of the fact that the majority of the congregational members of the DRC are still representing the minority white population group. However, the recipients of services by 
the DRC, according to the study that informed this article, consisted of both members of the various congregations and members of the larger communities (across race and language) in which those congregations were situated (Van der Westhuizen 2013:44-45). These findings were consistent with those of Van Wyk (2013:9), who refers to two studies within the DRC during 2006 and 2010. The mentioned studies illustrated a growth in community involvement by congregations from $28.5 \%$ in 2006 to $40 \%$ in 2010 .

The legacy of the apartheid era is a critical component when one is investigating social injustice in present-day South Africa (Handmaker \& Berkhout 2010:2). Von Broembsen and Davis (2008:1-2) assert in this regard that actions related to addressing social injustices in post-apartheid South Africa have mainly focused on civil and political rights. The authors, however, note that the expectations of many of the country's poor and marginalised have not been met and that the "constitutional protections" in this regard have largely not been realised. The link between social injustice and poverty is therefore accentuated. This then results in an experience of disillusionment and frustration deriving from a sense of being unjustly treated.

The consequences of poverty and unemployment affect human dignity profoundly. At the same time, one should also consider that the exclusion from practices to address poverty and unemployment is in itself also a violation of dignity (Chambers 2006:3; Kakwani 2006:20). In addition, victims of crime who feel unprotected by the law become victims of social injustice as their sense of security is affected by the crime. This feeling of insecurity often leads to a sense of dissatisfaction, conflict and a lack of cooperation between groups (Smith, 2005:46). As mentioned before, the sense of dissatisfaction then impacts on the social interactions and processes within a society (Farooq 2012:13).

In line with these descriptions of experiences of social injustice, the United Nations' Department of Economic and Social Affairs (2005:14) describes the link between poverty and unemployment, on the one hand, and social injustice, on the other, in terms of the theory of structural poverty as follows: 
While poverty has many dimensions, its two fundamental aspects are the lack of economic power owing to low incomes and assets, and the lack of socio-political power, as reflected in the limited access to social services, opportunities and information and often in the denial of human rights and the practice of discrimination.

The goal of sustained poverty reduction can thus not be achieved unless social justice is emphasised. With this identification in mind, for the purpose of this article social justice refers to the implementation of dignified treatment of all people and groups, as well as equal access to services, availability of services and opportunities for development (Ozoemena 2010).

\section{The social function of the church at congregational level}

This article specifically investigates the current activities of the DRC at congregational level pertaining to the social issues of poverty, unemployment and social injustice. Smit (2008c:105-106) notes that it is of critical importance that we investigate what congregations do and to learn from each other. He argues that we often forget that the true relevance, function and role of the church become clear when we look at what "average people on ground level" are doing.

Schoeman (2012:1) reflects on the involvement of the DRC in a changing South African society since the transition from a minority government to an open democratic society, as well as the subsequent "opening up of South African society to the world and influences such as globalisation and world trends". Importantly, however, for Schoeman these changes not only forced the country's citizens to adapt to being part of what Thomas L. Friedman has termed a "flat world", "with all its consequences". In a fundamental way, they also influenced the church community and its members, "who could not escape from these changes”. According to Schoeman (2012:1),

...it is clear that churches are now operating in a cultural and a socio-political environment very different from the one before 1990. These changes in the South African context are having far-reaching consequences for the role and involvement of churches in society. The playing field has changed and therefore the critical question is: How is this impacting the church? 
With these changes in mind, Smit (2008a; 2008b) explores the social relevance of the church and postulates that the church does indeed have a social function and that this function is uniquely founded upon its role within present-day society. The specific challenge is not to take on other roles that belong to other role-players (e.g. the business sector, government) in our society, but to rather ensure that the church becomes clear about its social function as one role-player within our broader society. This argument is supported by Schoeman (2012:7), who asserts that especially congregations can make an "enormous contribution" to the wellbeing of South African communities. For Schoeman, this unique role is embedded in the fact that congregations represent the moral order and human values of South African people, and could therefore be seen as a pertinent source of moral and spiritual capital.

Linking the mentioned changes in South African society and the social function of the church at congregational level, Schoeman (2012:6) concludes that "change will take place through the ministry of ... [a] congregation". In this regard, he also quotes Van Gelder who asserts that "a congregation should expect change as the Spirit works to bring about transformed lives living out of a new nature" (in Schoeman 2012:6). This perspective is in turn supported by Smit (2008a:72-75; 2008c:105-106) who, by taking the public worship of congregations as point of departure, argues that local congregations constitute the locus of the Christian church. Consequently, it is within this location, in particular through the practices of public worship, that members of a congregation develop particular attributes. For instance, formation takes place when members are actively encouraged to practise not only forgiveness, tolerance and thankfulness, but also a life of love, social justice and good citizenship. Through these attributes the unique calling of congregational members is developed so that they can become a "new community" (a koinonia) that not only cares for each other but also develops relationships of care and solidarity (diakonia) with the weak, poor and marginalised in society.

The social relevance of the church in post-apartheid South Africa could, therefore, be viewed in terms of its ability to assist members at the congregational level to practise their Christian beliefs and calling, thereby contributing to the wellbeing of members of society. This includes a focus on economic aspects, healthy citizenship, the development of healthy 
homes and family life, care for each other, responding and attending to those in need, ensuring that justice is done in all areas of life, taking care of the earth, and participating in public debate about issues that affect the wellbeing of South African people (Nessan 1999:113; Smit 2008b:88-90).

In what could also be regarded as directly relevant for a specifically South African perspective, Nordstokke (2009:46), a Norwegian scholar of diaconal studies, propagates the empowerment of congregational members as a significant process in which the dignity of people is affirmed and defended, peoples' rights are advanced and promoted, processes of empowering people are initiated, space is created for giving people access to rights, participation and responsibility in society (building citizenship), and the building-blocks for societal transformation are laid. The social function of the church, especially at congregational level, could therefore be viewed as "social ministry", which refers to any corporate effort that impacts on society or that improves the quality of life outside the congregation (Unruh \& Sider 2005:28).

Alston (2002:109) explains that the church does not preach the gospel in a vacuum, but in relation to the specific human realities, needs, questions, problems and possibilities of the world in which the church lives. The authors of this article draw a link between Alston's viewpoint and the community development approach. This approach requires that one has to view the contribution of congregations in terms of their capacity, organisational structures and available resources (Pretorius, 2013:5). Moreover, such an approach requires long-term outcome-based strategies, sustainability and specialist knowledge. Sustainability is dependent on the positive interaction between being a congregation and being a community. This means that congregations must be active participants in community issues (Orsmond 2012:2; Swart \& Orsmond 2011). Slenderbroek-Meints (2014:18-19) suggests that such active participation - which should entail the establishment of sustainable and effective services - is directly dependent on the motivation (internal and external) of congregational members, the capacity of the congregation (networks and resources) and reaction on opportunities (i.e. the ability to identify community needs and local resources to address those needs). It implies that the congregation does not act as a merely passive observer, but as an active participant standing alongside others. 
In terms of the focus of this article, the perspective of Handmaker and Berkhout (2010:x) can be considered as equally relevant when they note that the church's efforts to address poverty and unemployment are one way of ensuring that social justice is implemented. A struggle for justice implies that the church and its members understand that human beings are dependent on social structures. The struggle is therefore aimed at exposing, in solidarity with those who are most affected, the causes of poverty and suffering, and at striving for change of the circumstances that sustain poverty (Batista 1994:19; Church of Norway 2008:11; Swart 2008:128, 133137; Swart 2010b:254-255).

It follows that congregational programmes and projects that stimulate a positive relationship between congregations and the communities in which they are situated are highly relevant strategies to make a positive contribution towards community development (Church of Norway 2008:15-27). Furthermore, congregations could contribute to social justice at the very least in terms of fair practices (regardless of race, language, age and gender), fair actions to address differences, and fair judgements of facts (Smith 2005:57). This means that the church's social function at congregational level should be embedded in services of benevolence to those in need, as well as acting as a "voice" for the poor and marginalised. This social function fosters congregational members who are prepared to contribute to society at large. Ultimately, it entails the ability to act as citizens who contribute to social justice through:

1. Empowered citizenship, in which case the citizens of a particular society or community know their rights and responsibilities, and have access to forums and processes to practice these rights and responsibilities;

2. Inclusive citizenship, in which case everyone in a particular community or society can participate in forums and processes and have the same access to opportunities;

3. Fair citizenship, in which case resources are distributed fairly in a particular society or community, and everyone has access to them (Department of Arts and Culture, 2012:55-57). 
The above-mentioned DRC study (Van der Westhuizen 2013) was informed by the perspectives outlined above. Against this backdrop the findings related to the nature and extent of current services offered by the DRC at congregational level in present-day South Africa will now be discussed.

\section{Research findings of a research project}

The research findings were obtained from a quantitative research study utilising a pre-experimental research design. The data were obtained through a questionnaire that was completed by the leadership - i.e. ministers, deacons and/or elders - of rural (54\%) and urban (46\%) congregations of the DRC, representing all nine South African provinces. The participating congregations were selected by means of a probability sampling method together with a stratified random sampling technique (Grinnell and Unrau 2008:160). A database of all DRC congregations in the different synodic areas was utilised for this purpose. The population consisted of 1160 DRC congregations, with representatives from $36.6 \%$ of the congregations completing the questionnaire. The questions were based on nominal and ordinal levels of measurement and responses were described statistically (Van der Westhuizen 2013:10-14). At the end of the questionnaire respondents were asked to provide qualitative data on the challenges and successes their congregations experienced. The findings are described in terms of the congregations' current involvement in moves to address poverty, unemployment and social injustice; an identification of the challenges and successes identified by the respondents concludes the discussion of the research findings (Van der Westhuizen 2013:37-93).

\subsection{Services addressing poverty}

The findings (Van der Westhuizen 2013:49-56) point towards two congregational strategies that were used, namely services that alleviate poverty and services that reduce poverty (Richmond, 2007:14).

In terms of poverty alleviation, congregations that were represented in this study focused on providing food and shelter. Food was provided by $69.4 \%$ of the congregations, of which $88.6 \%$ provided and distributed food parcels, $60 \%$ ran feeding schemes in the communities and $48.6 \%$ were involved in school feeding schemes. In terms of shelter, a minority of the congregations 
provided housing, while the majority were involved in distribution of blankets (88.6\%) and clothing (82.9\%).

Services that were aimed at the reduction of poverty were linked to Maser's (1997:191-192) description of sustainable community development principles. A total of $46.4 \%$ of congregations focused on psycho-social development. This entails the development of networks and partnerships with service providers (62.9\%). An interesting aspect was that successful partnerships were mainly formed with faith-based and non-governmental organisations. Partnerships with governmental service providers that were viewed as effective were reported by $11.4 \%$ of the respondents. On a spiritualcultural level, $51.4 \%$ of the respondents identified programmes focusing on encouragement to become involved with others (i.e. taking responsibility for oneself and others). This aspect relates to the principle of unity. The respondents noted that the strengthening of families (42.9\%) as a primary support system and development of relationships in the community (28.6\%) as a secondary support system received attention. This was also related to the principle of self-determination. In this regard, 34.3\% of congregations worked according to this principle, which entails that the beneficiaries must participate in the identification of needs, as well as the planning and implementation of services to address these needs. Additionally, $45.7 \%$ of respondents reported that beneficiaries were encouraged to take some form of responsibility for services. Educational programmes did not receive much attention, though skills development programmes (31.5\%) and problemsolving workshops (5.7\%) were identified in this regard. An important aspect is that congregations encouraged and utilised members' access to resources $(54.3 \%)$, knowledge (51.4\%) and skills (51.4\%) to find creative ways to reduce poverty. Poverty reduction was also linked with services that address unemployment. This will be described next.

\subsection{Services addressing unemployment}

The findings (Van der Westhuizen 2013:57-62) relate to Weyers' (2011:155) description of community development. The community is empowered to create employment and to ensure access to employment opportunities. This requires the development of skills and a self-help attitude. For this to happen, networks are needed, resources must be developed and mobilised, and leadership skills must be developed (Bradshaw 2006:14). 
The respondents provided information that points to services that lead to empowerment of individuals. Personal empowerment programmes were provided by $20 \%$ of congregations and focused on substance abuse $(28.6 \%)$, literacy (22.9\%), financial literacy (17.1\%) and skills to access employment opportunities (14.3\%). Skills development was provided by a minority of congregations (17.1\%) and was based on specific skills that were identified as being needed in the labour market. The development of entrepreneurial skills was addressed by $11.4 \%$ of congregations. The primary focus was on marketing of skills and products (14.3\%), facilitating access to resources to start new businesses and the development of a business plan (8.6\%).

The empowerment-focused services were supplemented with emergency (i.e. short-term) support by $40 \%$ of congregations. This included once-off support to pay rent or electricity (62.9\%) and debt management and/or mediating cheaper services (e.g. school and medical fees) (28.6\%).

\subsection{Services addressing social injustice}

As mentioned previously, the recipients of services by the DRC represented both members of the participating congregations and members of the larger communities in which those congregations found themselves. The respondents' understanding of the term "social injustice" was not asked. They were, however, provided with the following description of the term prior to completing the questionnaire: Social justice refers to providing all members of a community with humane treatment, access to services that are provided in a respectful manner and opportunities for development (Ozoemena 2010). In addition, it requires a long-term commitment to identify ways to identify and combat existing social injustice practices (Mische 2007).

The link between poverty, unemployment and social injustice was explained above with reference to the theory of structural poverty (Bradshaw, 2006:4; Loewen, 2009:7). Oezemena (2010) also links poverty and unemployment with social injustice. This author explains that poverty alleviation needs to be focused on efforts to ensure employment opportunities for all. If certain groups in a society are still excluded from opportunities to move out of poverty, the consequence is social injustice. However, poverty alleviation leads to social justice when marginalised groups are empowered 
and included not only in employment opportunities, but also in active participation in processes that affect them.

The respondents indicated that services placed an emphasis on participatory processes rather than employment opportunities (Van der Westhuizen 2013:63-81). A participatory process involves the general public in the planning, implementation and evaluation of services. It includes transmitting information (unidirectional), consultation (bidirectional and active partnerships (Slocum 2003:9). For the purpose of this article, it refers to the involvement of the recipients of services. Accordingly, social injustices were addressed by congregations through awareness programmes, mobilisation of communities and encouragement of active citizenship. Awareness programmes were provided by $47.1 \%$ of congregations, of which $48.6 \%$ focused on the rights of people with disabilities and $45.7 \%$ focused on women's and children's rights. A total of $25.7 \%$ of congregations mobilised communities through forums and networks that address specific social issues (e.g. xenophobia). This aspect was also related to the encouragement of active citizenship, as $34.3 \%$ of congregations encouraged their members to become actively involved in community forums and processes to address social issues.

The respondents identified links with resources, the development of morality and the development of life skills as other aspects that received attention to address social injustices. Involvement in networks (27.1\%) entailed that people were linked with educational (34.3\%) and medical (20\%) service providers. The development of moral values among congregational members received attention by $67.1 \%$ of the participating congregations. The focus was on the provision of marital and child care information $(65.7 \%)$ as well as on marriage and parent-child counselling (68.6\%). Life skills programmes by $55.7 \%$ of congregations focused on parental skills (54.3\%) and on relationship/communication skills (57.1\%).

\subsection{Perceived challenges in delivering of services}

The respondents identified lack of funds as an important factor impacting on congregations' ability to render services. This situation was further exacerbated by the reality of poverty in communities, which in turn affected the income of congregations. The respondents also reported that a lack of access to, and support from, governmental service providers was 
a frustration in providing services. According to respondents, this has a bearing on the issue of social justice, because this same lack of access was also experienced by community members (Van der Westhuizen 2013:8288).

Another challenge identified concerned the generally advanced age of many congregational members. This impacted on the availability of human capacity in service delivery, while congregational members were often not willing to become involved in volunteer work. In this regard respondents reported that specific social issues required special expertise.

Substance abuse, teenage pregnancies and child neglect in the larger community were also viewed as issues where congregations needed to work in partnership with professionals to address the issues effectively. The lack of access to, or availability of, a professional knowledge base to assist with services regarding these issues were noted as specific concerns.

Lastly, respondents expressed concern regarding what they called the "receiving culture" among beneficiaries. Respondents explained this term as meaning that beneficiaries did not want to become involved with the planning and implementation of services. It, therefore, meant that services provided short-term relief, but did not lead to long-term change that addresses poverty in a sustainable manner.

\subsection{Perceived successes in delivering of services}

Respondents reported that where congregational members were willing to share resources, knowledge and skills, it became easier to provide services. Congregations experienced better successes once the attitudes of congregational members had changed. This relates to the focus on the development and encouragement of active citizenship (Van der Westhuizen 2013:89-93).

Such changed attitudes provided congregations with infrastructure, increased capacity and opportunities to find creative ways to plan and implement services. Furthermore, respondents noted the value of wellplanned programmes and projects, and stressed the need for leaders with management skills. Joint services with other service providers led to success, because of the sharing of resources, knowledge and skills. 


\section{Becoming even more deeply and more effectively engaged: three areas of strategic concern}

The findings described above highlight the fact that the DRC is indeed addressing the threefold challenge of poverty, unemployment and social injustice at congregational level in a meaningful way. In what can be anticipated to be the DRC's own striving at congregational level to become even more deeply and more effectively engaged with these social challenges, the following recommendations are aimed at providing some guidelines towards this end. In particular, the identification of structural poverty and the way it sustains the threefold challenge of poverty, unemployment and social injustice serves as a guide for what is being proposed. The focus is therefore on ensuring that the contribution of the church - in this case more specifically the contribution of congregations of the DRC - is aimed at reducing vulnerability resulting from a lack of assets, resources and opportunities, as well as on the ability to deal with the reality of social problems (Richmond 2007:11).

Recommendations focus on three areas of congregational engagement: the role of congregations in representing the "voices" of people; the focus of congregational services; and the empowerment of congregations.

\subsection{Representing the "voices" of people}

This area of congregational engagement is aimed at addressing structural poverty through a combination of at least three facets: the promotion of inclusive citizenship (Department of Arts and Culture, 2012:55$57)$; processes in which the dignity of people is affirmed and defended (Nordstokke 2009:46); and acknowledging that people are dependent on social structures that strive for changing the circumstances that sustain poverty (Batista, 1994:19; Church of Norway 2008:11; Swart 2008:128, 133137; Swart 2010b:254-255).

Nyiawung (2010) explains that the concept of democracy must be conceptualised and implemented in practice, and that this should lead to a society where social justice is not only spoken about but also practised. The church, specifically at congregational level, serves as a moral guide in this regard. Gordon (2012:21) refers to an advocate role of the church in terms of three approaches, namely advocacy for, with and by the poor or 
those affected by a situation. The author emphasises the fact that the most sustainable form of advocacy is often that done by those who are directly affected by a situation, but that capacity building may be needed before this can happen.

The church should furthermore make sure that it truly represents the "voices" of the people. This will then not only refer to the members of the congregation, but to all members of the community who are affected by the social issues addressed by the congregations. To become an advocate towards this end and an agent of true empowerment would entail that the DRC should take new cognisance at congregational level of the importance of information and communication as vehicle for empowerment. Congregations, communities and the relevant governmental institutions should be informed about social issues and services that are provided especially at the local level (e.g. the results of this research study). Active communication between all the role-players should lead to a mutual understanding of the nature of partnerships, the focus of services provided by different role-players on grassroots level and the way that these services could complement each other to provide holistic support to communities.

\subsection{The focus of services}

As mentioned earlier, the focus of services can be divided into two categories, namely poverty alleviation and poverty reduction. In terms of poverty alleviation, as one mode of delivering services to address poverty, congregations should continue to render short-term emergency support to address basic human needs (i.e. food and shelter). Yet, they should importantly also engage in network and partnership formation to ensure a fairer distribution of resources, knowledge and skills. Swart (2010a) agrees that networks and partnerships between different sectors to address social issues are important. However, he also argues that an emphasis on the importance of networks and partnerships often leads to a preoccupation with the formation of networks and partnerships at the expense of a more concentrated focus on the actual issues that should be addressed and the activities of implementation that should emanate from such a focus (cf. Swart, 2010a:25-28). In other words, if networks and partnerships do not lead those involved in addressing the expressed needs of the people on grassroots level as the primary focus, social injustices are maintained 
instead of being dealt with. Therefore, services should be planned and implemented based on a clear analysis of the context.

A conscious decision and plan of action is needed to stimulate participatory practices. Considering that beneficiaries of services are often not willing or motivated to participate in the planning, implementation and evaluation of services, Slocum (2003:11) postulates that this aspect should be seen as a long-term process. Sharing information regarding the reasons for involvement, the specific nature of the involvement and the advantages of involvement should form key to the process of including beneficiaries in the different processes. Beneficiaries should be educated and encouraged to take ownership of these services, as the long-term aim should be to develop a self-help culture.

Not least, however, prevention of poverty and poverty reduction should focus on the active practising of Christian values and principles. On a congregational level, members should be encouraged to become involved based on a specific belief system. Beyers (2014:4-7), in support of this perspective, refers to poverty as a human condition whereby religion and its institutions have the potential to make a unique contribution to address poverty through three interrelated functions: firstly, by going beyond material concerns to focus on the spiritual dimension of human wellbeing; secondly, by teaching particular ethical values that would lead to more appropriate responses towards addressing poverty; and, thirdly, by playing an active role in alleviating poverty through appropriate action.

Indeed, collective work and involvement in community issues should ensure that people become involved in their own futures. The aim is to promote empowered citizenship (Department of Arts and Culture, 2012:5557). And it is with this in mind that the utilisation of networks and the use of collective knowledge and skills should focus on life skills, employment opportunities and income-generating programmes. The aim should be to create opportunities where human potential can develop and where people become involved in finding solutions for their own and societal problems. Emphasis should be placed on building self-assurance, developing selfrespect and taking ownership of problem-solving initiatives, which in turn should entail that local people (the beneficiaries of services and actions) be encouraged to become involved in the planning and development of 
actions, network initiatives with other organisations who are involved in the same social issues, identification and utilisation of available assets in the community, and celebration of small successes with all the parties involved (Cavaye 2002:3). Ultimately, the final outcome should be that the actual implementation of programmes leads to the empowerment and independence of people on the ground (Swart, 2010a:27).

\subsection{Empowerment of congregations}

In order for members of congregations to become active citizens, they should be empowered through sustainable networks, opportunities to develop knowledge and skills to attend to real and felt needs, and sufficient communication and information to develop a clear vision of their congregations' role in the community where they are situated. Furthermore, the necessary leadership skills should be developed to ensure that leaders are equipped to lead congregations and communities towards sustainable community development. In this process congregational members should also be provided with training opportunities to become equipped with knowledge and skills to address specific social issues in very specific contexts.

Weyers (2011:403-407), in a helpful way, identifies the following domains that should be the focus of empowering individuals, groups and communities: emotional (e.g. identification and dealing with emotions, creativity), physical (e.g. lifestyle choices), social and civil (e.g. networks and civic responsibility), occupational (e.g. employability, career choice), environmental (e.g. managing the environment), financial and material (e.g. budgeting), spiritual and cultural (e.g. personal belief system, cultural awareness) and intellectual (e.g. critical thinking). Based on this identification, Weyers furthermore proposes various creative ways to create learning opportunities, such as workshops, participatory theatre and art, and informal and formal training.

In summary, empowering congregations should strive to assist members to become active citizens, who are empowered through inclusion in the relevant processes and who have access to opportunities (Department of Arts and Culture, 2012:55-57). A further outcome should be that the dignity of all people should be affirmed and defended, and that people will work in solidarity towards a healthy society (Nordstokke 2009:46). 


\section{Conclusion}

The above recommendations are supported by perspectives from the existing literature in that they plead for the development of positive and constructive relationships and partnerships, and for stressing the importance of including beneficiaries (cf. Patel 2009:242; Handmaker \& Berkhout 2010:ii; National Planning Commission, 2011:14; Swart, 2010a:24-28).

In summary, it is recommended that the DRC's congregational role in contexts of poverty, unemployment and social injustice be based on advocating and implementing strategies that promote human dignity. This should lead to opportunities and a space where people could develop and participate in mutually beneficial ways. Two key aspects should receive attention, namely partnerships and the encouragement of participation by beneficiaries (cf. Nordstokke 2009:46). The participation of the beneficiaries should be aimed at empowering them to become involved in the improvement of their lives, and could be viewed as one way to address dependency on formal structures (e.g. governmental services and funding).

As mentioned before, the DRC was an active partner of the previous South African government and social services by the DRC were delivered within the framework of the legislation and policy documents regulated under the apartheid dispensation. Significantly, however, the findings that were discussed in this article show that congregations of the DRC have continued to play an active role in addressing social issues in the new democratic South Africa. Yet in order to still become more effective in this regard, future actions will require that the congregational services of the DRC should be more pointedly planned according to specific contexts. The DRC's role at congregational level is to continue with emergency and shortterm support, but this should crucially, and even more than is currently the case, be expanded to include programmes aimed at long-term change on the basis of a theological commitment to human dignity and social justice. This need for a focus on long-term solutions that lead to social improvement, empowerment and change is evident when one considers that the key aspects that were identified as concerns have remained the same from 1994 until today. The DRC should therefore ensure that it becomes an acknowledged role player at congregational level with other relevant actors, and that the focus of the services rendered should include and emphasise 
the development of poverty-reduction programmes. To be able to work towards effective change, the beneficiaries should be empowered to become the "masters of their own development."

\section{Bibliography}

Alston, WM 2002. The Church of the Living God: A Reformed Perspective. Louisville, KY: Westminster John Knox.

Batista, I 1994. Civil society: A paradigm or a new slogan? The Ecumenical Review, 44 (1):12-20.

Beyers, J 2014. The effect of religion on poverty. HTS Teologiese Studies/ Theological Studies, 70(1), Art. \#2614, 8 pages. http://dx.doi.org/10.4102/ hts.v70i1.2614

Bradshaw, TK 2006. Theories of Poverty and Anti-Poverty Programs in Community Development. Working Paper Series. Columbia, MO: The Rural Poverty Research Center. [Online] www.rupri.org/Forms/WP06-05.pdf [Accessed: 13 February 2015]

Cavaye, J 2002. Building Sustainable Communities - A Resource Kit. Adelaide: Office of Regional Development, Government of South Australia.

Chambers, R 2006. What is poverty? Who asks? Who answers? UNDP, International Poverty Centre, Poverty in Focus, December 2006:3-4.

Church of Norway 2008. Plan for Diakonia. Oslo: National Council of the Church of Norway.

Clark, DJ, Fage, JD, Oliver, RA \& Roberts, AD 1975. The Cambridge History of Africa. London: Cambridge University Press.

Cohen, A 2009. The Multidimensional Poverty Assessment Tool:

Design, Development and Application of a New Framework for Measuring Rural Poverty. Rome: International Fund for Agricultural Development.

Department of Arts and Culture 2012. Creating a Caring and Proud Society. Pretoria: Department of Arts and Culture. 
Department of Economic and Social Affairs, United Nations 2005. The Inequality Predicament: Report on the World Social Situation 2005. New York: United Nations. [Online] www.un.org/esa/socdev/rwss/docs/2005/ rwss05.pdf. [Accessed: 22 January 2015]

Department of Social Development 2013. Framework for Social Welfare Services. Pretoria: Department of Social Development.

Farooq, M 2012. Social Interaction \& Social Process. [Online] http://www.slideshare.net/kakafarooq/social-interaction-and-social-process [Accessed: 15 April 2015]

Fourie, J 2006. The South African Poor White Problem in the Early 20th Century: Lessons for Poverty Today. Stellenbosch Economic Working Papers 14/06. Stellenbosch: Department of Economics and Bureau for Economic Research, Stellenbosch University.

Gordon, G 2012. Advocacy Toolkit: Understanding Advocacy. Teddington: Tearfund.

Grinnell, RM \& Unrau, YA 2008. Social Work Research and Evaluation: Foundations of Evidence-based Practice. New York: Oxford University Press.

Handmaker, J \& Berkhout, R (eds) 2010. Mobilising Social Justice in South Africa: Perspectives from Researchers and Practitioners. Pretoria: Pretoria University Law Press.

International Labour Organization 2013. Global Employment Trends: Recovering from a Second Jobs Dip. Geneva: International Labour Office.

Ipsos 2014. People's Poll: The "People's Agenda" puts job creation as priority. [Online] http://www.ipsos.co.za/SitePages/lpsos\%20Poll\%20The\%20 "People's\%20Agenda"\%20puts\%20Job\%20Creation\%20as\%20priority.aspx [Accessed: 12 February 2014]

Kakwani, N 2006. Poverty and wellbeing. UNDP, International Poverty Centre, Poverty in Focus, December 2006, 20-21.

Kritzinger, JJ 1994. The Dutch Reformed Church (NG Kerk) and development: Three models. Journal of Theology for Southern Africa, 87(June):49-61. 
Levinsohn, J 2007. Two Policies to Alleviate Unemployment in South Africa. Michigan: Ford School of Public Policy.

Lidzén, L 2008. A Comparative Study of the Social Welfare Provided by Three Christian Churches in Accra, Ghana. Högskolon I Grave: Institutionen för humaniora och samhällsvetenskap.

Loewen, G 2009. A Compendium of Poverty Reduction Strategies and Frameworks. Waterloo, Ontario: Tamarack Institute for Community Engagement.

Maser, C 1997. Sustainable Community Development: Principles and Concepts. Delray Beach: St Lucie Press.

Ministry of Finance, Republic of South Africa 2014. Media statement: 2014 budget continues to support economic growth and job creation. Cape Town: Ministry of Finance, Republic of South Africa. [Online] http://www.treasury.gov.za/comm_media/press/2014/2014022601\%20-\%20Jobs.pdf [Accessed: 9 June 2015]

Mische, PM 2007. The significance of religions for social justice and a culture of peace. Journal of Religion, Conflict and Peace, 1(1). http://www.religionconflictpeace.org/vol_1_issue_1.

Moloi, L 2015. Please sir, I want some more... Fast Facts, 5(285):1-2.

Narayan, D, Pritchett, L \& Kapoor, S 2009. Moving Out of Poverty, Volume 2: Success from the Bottom Up. Washington: The World Bank and Palgrave Macmillan.

National Planning Commission 2011. National Development Plan 2030. Pretoria: Office of the Presidency, South African Government. [Online] http://www.gov.za/sites/www.gov.za/files/npc_diagnostic_overview_1.pdf [Accessed: 16 June 2015.

National Development Agency 2014. State of Poverty and its Manifestation in the Nine Provinces of South Africa. Johannesburg: NDA. [Online] http://www.nda.org.za/docs/NDA_Strategy_2014_SD_final.pdf [Accessed: 16 June 2015]

Nessan, CL 1999. Beyond Maintenance to Mission: A Theology of the Congregation. Minneapolis, MN: Fortress. 
Nordstokke, K 2009. Diakonia in Context: Transformation, Reconciliation and Empowerment. Geneva: The Lutheran World Federation.

Nyiawung, MD 2010. The prophetic witness of the church as an appropriate mode of public discourse in African societies. HTS Theological Studies, 66(1), Art. \#791, 8 pages. DOI: 10.4102/hts.v66i1.791

Orsmond, E 2012. The church and community development - challenges with others. Presentation delivered at the Symposium "Theology in times of change", Faculty of Theology, Stellenbosch University, 23 January 2012.

Ozoemena, R 2010. Poverty alleviation strategies in South Africa: Creating dignified living for women through social justice and development. Consultancy Africa Intelligence. [Online] http://www. consultancyafrica.com/index.php?option=com_content\&view=article\&id=526:pover ty-alleviation-strategies-in-south-africa-creating-dignified-living-for-women-throughsocial-justice-and-development\&catid=59:gender-issues-discussion-papers\&ltemid=267 [Accessed: 24 November 2012]

Patel, L 2009. Social Welfare and Social Development in South Africa. $2^{\text {nd }}$ Edition. Cape Town: Oxford University Press.

Pretorius, D 2013. Revitalising the role of the church in socio-economic development. A Presentation to church leaders, Victory Ministries International, Port Elizabeth, 11 July 2013. [Online] http://tcn.org.za/wpcontent/uploads/2013/07/Development-Strategy-for-Metro-10-7-13-02.pdf [ Accessed: 16 June 2015]

Richmond, J 2007. The Measurement of Poverty in South Africa Project:

Key Issues. Johannesburg: Studies in Poverty and Inequality Institute. [Online] Viewed, from http://www.treasury.gov.za/publications/other/ povertyline/SPII\%20document.pdf [Accessed: 16 June 2015]

Schoeman, WJ 2012. The involvement of a South African church in a changing society. Verbum et Ecclesia, 33(1), Art. \#727, 8 pages. http://dx.doi.org/10.4102/ ve.v33i1.727 
Slendebroek-Meints, J. 2014. Onderzoek binnen de CGK, NGK en GKV naar huidig en gewenst diaconaat en wat daarvoor nodig is. Zwolle: Centrum voor Samenlevingsvraagstukken. [Online] http://www.viaa. nl/ /media/Files/Onderzoek/CvSv/Publicaties/14_0310_HELP.ashx [Accessed: 16 June 2015]

Slocum, N 2003. Participatory Methods Toolkit: A Practitioner's Manual. Brussels: Joint publication of the King Baudouin Foundation and the Flemish Institute for Science and Technology Assessment (viWTA) in collaboration with the United Nations University - Comparative Regional Integration Studies (UNU/CRIS).

Smit, DJ 2008a. Oor die kerk as 'n unieke samelewingsverband. In DJ Smit, Geloof en Openbare Lewe. Versamelde Opstelle 2: Spesiale uitgawe in die Beyers Naudè Centre Series on Public Theology. Stellenbosch: SUN Press. 69-81.

Smit, DJ 2008b. Oor die unieke openbare rol van die kerk. In DJ Smit, Geloof en Openbare Lewe. Versamelde Opstelle 2: Spesiale uitgawe in die Beyers Naudè Centre Series on Public Theology. Stellenbosch: SUN Press. 83-99.

Smit, DJ 2008c. Oor die kerk en maatskaplike uitdagings in ons land. In DJ Smit, Geloof en Openbare Lewe. Versamelde Opstelle 2: Spesiale uitgawe in die Beyers Naudè Centre Series on Public Theology. Stellenbosch: SUN Press. 101-114.

Smith, DM 2005. On the (im)possibility of social justice in South Africa. Transformation: Critical perspectives on Southern Africa, 58(2005):4565.

Statistics South Africa 2013a. Millennium Development Goals Country Report 2013: The South Africa I Know, the Home I Understand. Pretoria: Statistics South Africa. [Online] www.statssa.gov.za/MDG/ MDGR_2013.pdf [Accessed: 12 December 2014]

Statistics South Africa 2013b. Poverty Trends in South Africa: An Examination of Absolute Poverty between 2006 and 2011. Pretoria: Statistics South Africa. [Online] http://beta2.statssa.gov.za/publications/ Report-03-10-06/Report-03-10-06March2014.pdf [Accessed: 12 December 2014] 
Statistics South Africa 2014. Unemployment Rates for 2014. Pretoria: Statistics South Africa. [Online] http://beta2.statssa.gov.za/publications/P0211/ P02111stQuarter2014.pdf [Accessed: 5 February 2015]

Steele, M 2006. Report on Incentive Structures of Social Assistance Grants in South Africa. Pretoria: Department of Social Development.

Swart, I 2008. Meeting the challenge of poverty and exclusion: The emerging field of development research in South African practical theology. International Journal of Practical Theology, 12(1):104-149.

Swart, I 2010a. Networks and partnerships for social justice? The pragmatic turn in the religious social development debate in South Africa. In I Swart, H Rocher, S Green, \& J Erasmus (eds), Religion and Social Development in Post-Apartheid South Africa: Perspectives for Critical Engagement. Stellenbosch: SUN Press. 15-36.

Swart, I 2010b. Church, mission and development: Revisiting the pragmatic debate. In I Swart, H Rocher, S Green, \& J Erasmus (eds), Religion and Social Development in Post-Apartheid South Africa: Perspectives for Critical Engagement. Stellenbosch: SUN Press. 243259.

Swart, I \& Orsmond, E 2011. Making a difference? Societal entrepreneurship and its significance for a practical theological ecclesiology in a local Western Cape context. HTS Theological Studies, 67(2), Art. \#1045, 11 pages. http:// dx.doi.org/10.4102/hts. v67i2.1045

Terreblanche, S 2002. A History of Inequality in South Africa. Pietermaritzburg: University of Natal Press.

Unruh, HR \& Sider, RJ 2005. Saving Souls, Serving Society: Understanding the Faith Factor in Church-based Social Ministry. New York: Oxford University Press.

Van der Merwe, WC 2012. The Dutch Reformed Church and social welfare in post-apartheid South Africa. In I Swart, A Gouws, P Pettersson, J Erasmus \& F Bosman (eds). Welfare, Religion and Gender in Post-apartheid South Africa: Constructing a South-North Dialogue, 145-164, Stellenbosch: SUN Press. 
Van der Merwe, WC 2014. Met Woord en Daad in Diens van God: Die Diakonaat van die NG Kerk in Postapartheid Suid-Afrika. PhD Proefskrif. Stellenbosch: Universiteit Stellenbosch.

Van der Westhuizen, MA 2013. Die Betrokkenheid van die NG Kerk by die Stryd teen Armoede, Werkloosheid en Maatskaplike Ongeregtigheid. Wellington: Algemene Sinode van die NG Kerk en Hugenote Kollege.

Van Wyk, C 2013. Hoe lyk gemeentes in die spieël? Kruisgewys, Junie 2013:6-14.

Von Broembsen, M \& Davis, D 2008. South Africa must address social justice. The South African Civil Society Information Service. [Online] http://sacsis.org.za/site/article/186.1 [Accessed: 15 April 2015]

Weyers, ML 2011. The Theory and Practice of Community Work: A South African Perspective. Potchefstroom: Xerox, PU for CHE.

World Economic Forum 2014. Global Risks Report 2014. Geneva: WEF. [Online] http://www3.weforum.org/docs/WEF_GlobalRisks_Report_2014.pdf [Accessed: 12 December 2014] 